\title{
Fabrication and Characterization of a Three-Dimensional Fibrin Gel Model to Evaluate Anti-Proliferative Effects of Astragalus hamosus Plant Extract on Breast Cancer Cells
}

\author{
Mozaffar Mahmoodi', Somayeh Ebrahimi- Barough', Shaghayegh Kamian², \\ Mahmoud Azami ${ }^{1}$, Mozhgan Mehri ${ }^{3}$, Mohammad Abdi,5*, Jafar Ai ${ }^{1 *}$
}

\begin{abstract}
Background: Breast Cancer (BC) is a malignancy with high mortality among women. Recently, scaffold-based three-dimensional (3D) models have been developed for anti-cancer drug research. The present study aimed to investigate the anti-proliferative effects of Astragalus hamosus (A. hamosus) in 3D fibrin gel against MCF-7 cell line. We have also evaluated anti-proliferative effect of $A$. hamosus differences between 3D and 2D cultures. Methods: The fibrin gel formulation was first optimized by testing the structural and mechanical properties. Then the cytotoxic effect of A. hamosus extract was assessed on MCF-7 cells by MTT assay. Cell apoptosis was evaluated using TUNEL method and flow cytometry. Cell cycle and proliferation were analyzed by flow cytometry. Apoptosis-related gene expression such as Bcl-2, caspase-3, -8 and -9 were quantified by real time-PCR. Results: TUNEL staining showed a significant damage accompanied with cell apoptosis. Flow cytometry analysis revealed that apoptosis increased after treatment with $A$. hamosus extract in 3D culture model compared to 2D culture. The $A$. hamosus extract arrested cell cycle in the $\mathrm{S}$ and G2/M phases in 3D model while in the 2D culture G0/G1 phase was affected. Treatment with A. hamosus extract led to upregulation of the caspase-3, -8 and -9 genes and downregulation of the Ki-67 in the 3D-culture compared with the 2D culture. Conclusion: These results indicated that $A$. hamosus extract could be used as a therapeutic candidate for $\mathrm{BC}$ due to its anti-proliferative effects. Furthermore, 3D fibrin gel could be better than 2D-cultured cells in simulating important tumor characteristics in vivo, namely, anti-proliferative and anti-apoptotic features.
\end{abstract}

Keywords: Astragalus hamosus- breast cancer- fibrin gel- three dimension cell culture model

Asian Pac J Cancer Prev, 23 (2), 731-741

\section{Introduction}

Breast Cancer (BC) is the most common cancer in women worldwide and the second cause of cancer death among them (Abbastabar et al., 2013; Ginsburg et al., 2017). Like other malignancies, the breast cancer undergoes genetic changes that alter the molecular mechanism of healthy cells and upset the balance between immune cells in breast tissue and mammary gland cells, leading to chronic inflammation and eventual malignancy (Montazeri et al., 2008; Pollard, 2009; Menbari et al., 2020). Disruption in family life, worrying about the future, fearing of death, decreased performance, mental disorders, and sexual problems are some social and familial complications for BC-suffering patientswhich induce a variety of stresses and cause mental and psychological disorders in their lives. Chemotherapy, radiation therapy, surgery, and hormone therapy are common BC treatments (Chie et al., 1999). Long-term chemotherapy causes many physical, sexual and psychological problems for patients due to mastectomy-related negative changes in the mental image of women (Fobair et al., 2006). Inappropriate therapeutic effectiveness, many side effects (Ginsburg et al., 2017), and resistance of some BC tumors to chemotherapy drugs need alternative treatments (Zhang et al., 2017) or new drugs having suitable protective or therapeutic effect on breast cancer (Abbastabar et al., 2013).

Although two-dimensional (2D) in vitro cytotoxicity models are traditional in pre-clinical studies for drug development, they could not simulate three-dimensional (3D) tumor environment (TME) and do not reflect

${ }^{1}$ Department of Tissue Engineering, Faculty of Advanced Technologies in Medicine, Tehran University of Medical Sciences, Tehran, Iran. ${ }^{2}$ Department of Radiotherapy Oncology, Imam Hossein Hospital, Shahid Beheshti University of Medical Sciences, Tehran, Iran. ${ }^{3}$ Department of Persian Medicine, Faculty of Medicine, AJA University of Medical Sciences, Tehran, Iran. ${ }^{4}$ Cellular and Molecular Research Center, Research Institute for Health Development, Kurdistan University of Medical Sciences, Sanandaj, Iran. ${ }^{5}$ Department of Clinical Biochemistry, Faculty of Medicine, Kurdistan University of Medical Sciences, Sanandaj, Iran. *ForCorrespondence: abdi@muk.ac.ir,jafar_ai@tums.ac.ir 
actual tumor responses to drugs. The cells cultured in 2D monolayers poorly retain their original phenotype (Bahcecioglu et al., 2020), and do not recapitulate the complexity of tumor microenvironment (Leonard and Godin, 2016) resulting in different cell-cell and cellmaterial interactions from actual in vivo behaviors (Duval et al., 2017; Noori et al., 2017). On the other hands, animal models are extremely useful to understand drug activity and metabolism; however, they are most costly and time-consuming (Bahcecioglu et al., 2020), have ethical concerns (Huang et al., 2013), and are most importantly do not reflect human responses to drug treatments (Bahcecioglu et al., 2020). Since tissue microenvironment can play an important role in cellular functions, we need to develop different laboratory models that can show how the structural and biochemical properties of tissue microenvironment have effect on tumorigenesis suppression. The 3D culture plays an important role in tumor biology and responses to therapeutic drugs by providing in vivo like microenvironment (Gurski et al., 2010; Huang et al., 2013). Huang (2013) (Huang et al., 2013) reported that the encapsulated MCF-7 cells in the hydrogel matrix during hydrogelation and cells residing in $3 \mathrm{D}$ have better grow than those $2 \mathrm{D}$ cultures. Treatment by an anti-cancer drug (cisplatin) causes a significant decrease of cell viability in hydrogels leading to provide evidence that the hydrogel is a promising $3 \mathrm{D}$ culture for drug testing. Consequently, 3D in vitro engineered models mimicking TME (Bahcecioglu et al., 2020), providing ethical and economic benefits, and bridging the gap between 2D and in vivo studies (Leonard and Godin, 2016; Yakavets et al., 2020) could be developed due to advancements in biomaterials and tissue engineering (TE) (Bahcecioglu et al., 2020).

Tissue engineering by its innovations in scaffold designs for engineering TME (Lequeux et al., 2012) provides a new approach to evaluate anti-BC therapy (Li et al., 2019a). Three-dimensional scaffold-based cell cultures having better morphology and function of differentiated cells as well as ability to select and control various culture factors including bioreactors and culture methods can be performed at a higher scale (Afewerki et al., 2019). Scaffold-based models developed for anticancer drug researches can be divided by origin into natural or synthetic and by structure into solid scaffolds or hydrogels (Lequeux et al., 2012; Carvalho et al., 2017; Mahmoodi et al., 2020). Polyurethane foam (Angeloni et al., 2017), nanoclays (Kar et al., 2019), silk fibroin (Wang et al., 2010), human decellurarized adipose tissue (Dunne et al., 2014), multi-walled carbon nanotubes (Akinoglu et al., 2017), polycaprolactone (PCL) fibers (Guiro et al., 2015), PCL-chitosan electrospun nanofibers (SimsMourtada et al., 2014), and agarose hydrogel (Vantangoli et al., 2015) are some natural and synthetic materials which have been used to make suitable scaffolds. Fibrin gel, among various natural and synthetic polymers used to design and simulate TME for breast tumor cells, is more desirable due to its salinity properties (Ahmed et al., 2008), high cell seeding efficiency, adhesive property, and improved cellular interaction (Malafaya et al., 2007).

Since anti-cancer chemotherapeutic agents damage normal cells, significant efforts have been made recently to identify natural compounds and related synthetic agents to prevent the development and recurrence of cancers (Greenwell and Rahman, 2015). Medicinal plants have been discovered and used in traditional medicine practices (Ahn, 2017), and remain as the basis of modern medicine (Shkondrov et al., 2019; Berezutskii et al., 2020; Borah and Banik, 2020; Darvishi et al., 2020). Numerous phytochemicals with potential or established biological activity have been identified (Ahn, 2017), and several anti-cancer chemotherapeutic drugs have been identified and isolated from medicinal plants (Borah and Banik, 2020). Traditional Persian medicine (TPM) as one of the most ancient categories of complementary and alternative medicine with the unique medical texts can be a good help in introducing new anti-cancer drugs (Bahramsoltani et al., 2017). The pterygium, scientifically named Astragalus hamosus ( $A$. hamosus), is one of the traditional drugs which has been shown to have analgesic properties, acute anti-inflammatory properties, and antioxidant activity, possibly by inhibiting prostaglandin synthesis (Lysiuk and Darmohray, 2016). Anti-cancer activity of A. hamosus having different mechanisms such as immune response modulation, inhibition of angiogenesis, and decytotoxicity has been well established (Krasteva et al., 2008; Shojaii et al., 2015). The active ingredients of this plant include unsaturated fatty acids, free amino acids, polyphenols, triterpenes, flavonoid glycosides and glycolipids (Hamedi et al., 2016). The flavonoid glycoside rhamnocitrin 4'- $\beta$-Dgalactopyranoside extracted from the leaves of the crown plays a significant role in the prevention of carcinoma by inhibiting free radicals and reducing the production of superoxide dismutase (SOD), catalase (CAT), glutathione peroxidase (GPx), glutathione S-transferase (GST) and lipid peroxidation (LPO) (Saleem et al., 2013).

According to the consumption of the fruit of A. hamosus in Iranian medicine sources, we engineered a 3D human BC model using MCF-7 cells in fibrin gel to mimic TME. A. hamosus was used as a kind of herbs as anti-proliferative agent in 3D fibrin gel against $\mathrm{BC}$ cell line. Moreover, the total hydroalcoholic extract containing flavonoids and saponins was used for the first time to investigate its anti-tumor effects in a three-dimensional environment.

\section{Materials and Methods}

Tissue collection and mechanical analysis of BC tissue

Breast cancer tissue specimens were obtained from the Iran Tumor Bank (ITB), and confirmed pathologically. The present study was approved by the Ethics Committee of Tehran University of Medical Sciences. To analyze mechanical properties of obtained tissues, tumor tissues were punched into cylindrical form at the thickness of 5 $\mathrm{mm}$ and diameter of $10 \mathrm{~mm}$. Then, the samples were fixed between the DMTA parallel plates, and fully immersed in phosphate-buffered saline (PBS) in a standard submersioncompression clamp configuration at $25{ }^{\circ} \mathrm{C}$. Two series of compressive tests were run on each tumor sample following an initial application of $9 \%$ pre-strain to ensure full sample engagement and homogeneous compression 
before measurement. A controlled compressive force was applied at constant rate of $0.003 \mathrm{~N} / \mathrm{min}$ in all tests. The mean Young's modulus (E) was obtained for each sample from the slope of the stress-strain curve in the low-strain elastic regime.

\section{Preparation and mechanical characterization of fibrin gels}

In order to achieve the viscoelasticity similar to natural tissue, different factors involved in gel formation were used according to the Table 1. Considering the Hasanzadeh (2019) method (Hasanzadeh et al., 2019) to make the fibrin gel, fibrinogen (Sigma-Aldrich, USA) was dissolved in $1 \mathrm{ml} \mathrm{M} 199$ solution (Sigma-Aldrich, USA) and transferred to a 6-well culture plate. Afterward, thrombin solution ( $120 \mathrm{U} / \mathrm{ml}$ in $1 \mathrm{M}$ sodium buffer, SigmaAldrich, USA), calcium chloride ( $\mathrm{CaCl} 2,1 \%(\mathrm{w} / \mathrm{v}))$, and fetal bovine serum (FBS, Gibco BRL, Germany) were added to each well. The culture plates were placed in an incubator at $37{ }^{\circ} \mathrm{C}$ for one hour to form a $3 \mathrm{D}$ network structure. After leaving from the incubator, the consistency (no degradation) of prepared gels were examined by placing at $25{ }^{\circ} \mathrm{C}$ for three hours. The samples 3 and 6 could be taken out of the laboratory for mechanical testing, and other samples were degraded and removed due to lack of necessary strength. The mechanical properties of the gels were investigated by the method used for BC tissue analysis.

\section{Preparation of the A. hamosus extract}

The A. hamosus extract was obtained from fruit of $A$. hamosus. After preparing the fruit of $A$. hamosus plant, the scientific name of the plant (Astragalus hamosus L.) was approved by the Herbarium of Pharmacy of Tehran University of Medical Sciences and its voucher specimen number was assigned as PMP-3610. The hydro-alcoholic extract was prepared by massaging the fruit in $70 \%$ ethanol and the extract was then filtered and concentrated with vacuum evaporator. Then, the dried extract was suspended in deionized water to yield different fractions (Saleem et al., 2013)..

\section{Determination of total steroid by Lieberman-Buchard test}

To standardize the product, the amount of total unsaturated sterols in the dried A. hamosus extract was measured by the quantitative Lieberman-Buchard test. Liebermann-Buchard reagent (LBR) was prepared according to the process described in literature (Adu et al., 2019). Different concentrations of standard cholesterol $(0.5,1,1.5,2$ and $2.5 \mathrm{mg} / \mathrm{ml})$ were prepared in chloroform, the absorption optical densities were measured at a wavelength of $640 \mathrm{~nm}$, and the linear calibration curve was plotted. One gram of the extract was dissolved in 30 $\mathrm{mL}$ of $70 \%$ methanol and then $20 \mathrm{~mL}$ of water was added to it. The mixture was poured into a decanter funnel and extracted three times with $10 \mathrm{~mL}$ of chloroform. The bottom solution was collected in a concentrator containing chloroform, and dried. After dissolving the dried powder in $10 \mathrm{~mL}$ chloroform, three test tubes containing $1 \mathrm{~mL}$ of the LBR, $1.5 \mathrm{~mL}$ of the sample and $1 \mathrm{~mL}$ of chloroform were prepared, and the optical absorptions were measured
Three-Dimensional (3D) Fibrin Gel Scaffold for Breast Cancer

at $640 \mathrm{~nm}$ to determine total steroids. A test tube consisting of chloroform $(2 \mathrm{~mL})$ and the sample $(1.5 \mathrm{~mL})$ was used as control sample.

\section{$I C_{50}$ determination by MTT assay}

The MCF-7 cell line was prepared from the International Centre for Genetic Engineering and Biotechnology (ICGEB; Tehran, Iran) were grown in DMEM/Ham's F12 culture medium (Invitrogen, Carlsbad, CA) supplemented with 10\% FBS (Gibco BRL, Germany) under common culture conditions $\left(37^{\circ} \mathrm{C}, 95 \%\right.$ humidity, and $\left.5 \% \mathrm{CO}_{2}\right)$. After cell seeding in a 96-well plate at density of 5000 cells/well for $24 \mathrm{~h}$, the supernatant was removed and 200 $\mu \mathrm{L}$ of different concentrations of the $A$. hamosus extract $(62.5 \mu \mathrm{g} / \mathrm{mL}, 125 \mu \mathrm{g} / \mathrm{mL}, 250 \mu \mathrm{g} / \mathrm{mL}$, and $500 \mu \mathrm{g} / \mathrm{mL})$ (Csupor-Löffler et al., 2009; Li et al., 2019b) and paclitaxel $(0.005 \mu \mathrm{M} / \mathrm{mL}, 0.01 \mu \mathrm{M} / \mathrm{mL}, 0.05 \mu \mathrm{M} / \mathrm{mL}$, and $0.1 \mu \mathrm{M} /$ mL) (Zuo et al., 2010; Vali et al., 2015) were added in any well separately, and incubated for 72 hours. To calculate IC50 (the half maximal inhibitory concentration) by MTT assay, $10 \mu \mathrm{L}$ of MTT solution $(5 \%(\mathrm{w} / \mathrm{v}))$ was added at the predetermined time, and incubated for four hours. After removing supernatants, $100 \mu \mathrm{l}$ of isopropanol was added to each well, incubated for $20 \mathrm{~min}$ to dissolve deposited formazan salt, and the absorbance at $570 \mathrm{~nm}$ with reference to $630 \mathrm{~nm}$ was determined using Biotek Synergy HTX microplate reader (Biotek, USA). Finally, cell viability was calculated using Eq.1 and IC50 was found by curve fitting on the viability data. Paclitaxel as a cytotoxic drug for BC treatment (Foglietta et al., 2018) was used as a positive control. Also, untreated MCF-7 cell was considered as negative control.

$$
\text { Cell viability }(\%)=\frac{\text { Average absorbance of sample at } 570 \mathrm{~nm}}{\text { Average absorbance of negative control at } 570 \mathrm{~nm}} \times 100(\text { Eq.1) }
$$

\section{Spheroid formation and three-dimensional (3D) cell} culture in fibrin gel

Fibrin gel was used as a hydrogel scaffold for encapsulation of MCF-7 spheroid cells. Due to the fact that the MCF-7 cells were adherent cells and had high tendency to adhere to the bottom of common culture plates, non-adherent plate was used to form cellular spheroids. The MCF-7 cell line was cultured in non-adherent plate. Briefly, enzymatic dissociated MCF-7 cells were suspended in the culture medium and the cell suspension $\left(2 \times 10^{5} \mathrm{cell} / \mathrm{ml}\right)$ was transferred to a sterile, non-adherent 8 -well plate and incubated under common culture conditions for 72 hours. The tumor spheroid formation was assessed visually after 24,48 , and 72 hours by taking optical images to calculate spheroid size. Finally, the MCF-7 spheroids were encapsulated in fibrin gel.

\section{Treatment of cancer cells under $2 D$ and $3 D$ conditions}

For $2 \mathrm{D}$ and $3 \mathrm{D}$ treatments, a total of $1 \times 10^{6} \mathrm{MCF}-7$ cells were seeded in a 6-well plate and total of $1 \times 10^{6} \mathrm{MCF}-7$ cells in spheroid shape were encapsulated in 3D fibrin gel for 24 hours, respectively. Then, the supernatant was removed and the samples were treated with $A$. hamosus extract and paclitaxel at their $\mathrm{IC}_{50}$ concentrations for 72 
hours. Paclitaxel was used as a positive control.

Molecular and biological assays to evaluate treatment efficiency

Apoptosis evaluation by TUNEL assay and flow cytometry

The terminal deoxynucleotidyl transferase-mediated deoxyuridine triphosphate nick-end labeling (TUNEL) assay was used for apoptosis evaluation by applying a available kit (In situ Cell Death Detection kit, Roche, Germany). MCF-7 spheroids were encapsulated in fibrin gel in 96-well flat-bottom plate and treated with $\mathrm{IC}_{50}$ concentrations of $A$. hamosus extract for 72 hours. Briefly, the spheroids were washed in PBS, fixed in $4 \%(\mathrm{w} / \mathrm{v})$ paraformaldehyde (PFA), washed in PBS, and stored in $70 \%$ ethanol at $4^{\circ} \mathrm{C}$ overnight. After being washed with $10 \mathrm{mM}$ Tris- $\mathrm{HCl}(\mathrm{pH} 7.6)$, the spheroids were incubated in methanol containing $0.3 \% \mathrm{H}_{2} \mathrm{O}_{2}$ for $10 \mathrm{~min}$ to quench endogenous peroxidase activity. Then, the cells were treated with proteinase $\mathrm{K}$ at $37^{\circ} \mathrm{C}$ for $30 \mathrm{~min}$. The spheroids were then incubated in the TUNEL reaction mixture at $37^{\circ} \mathrm{C}$ for $60 \mathrm{~min}$ followed by incubating in horseradish peroxidase (Santa Cruz, Germany) solution for $30 \mathrm{~min}$. The color reaction was developed in 3 , 30-diaminobenzidine (DAB, Roche; $0.5 \mu \mathrm{LAB}$ and $1.5 \mu \mathrm{l}$ peroxide buffer) for $10 \mathrm{~min}$. A set of cells was incubated in the absence of TUNEL as a negative control. Using TUNEL procedure, apoptotic cell nuclei will be colored dark brown and were observed under a light microscope.

Moreover, apoptotic cells were assessed by flow cytometery (CyFlow SL, Partec-Germany) using Annexin V-FITC Apoptosis Detection Kit (Biovision, USA) according to the manufacturer's instructions. Data from independent triplicate experiments were calculated to analyze the number of apoptotic cells.

\section{Proliferation assay}

The MCF-7 cell was fixed with 4\% PFA and permeabilized with $0.1 \%$ Triton $\mathrm{X}-100$ at room temperature. The cells were incubated with anti-Ki-67 antibody (ab16667, Abcam, Cambridge, MA, USA) overnight, and fluorescein-conjugated goat anti-rabbit IgG (A-21428, Life Technologies) as secondary antibody.

\section{Cell cycle analysis}

The MCF-7 cells were harvested in ice-cold PBS, fixed in ice-cold $70 \%$ ethanol to synchronize the cell cycle, resuspended in cold PBS. RNAase $(2 \mu \mathrm{g} / \mathrm{ml})$ was added and incubated at $37^{\circ} \mathrm{C}$ for $30 \mathrm{~min}$, followed by cultivation in $400 \mu \mathrm{L}$ propidium iodide (PI) for $40 \mathrm{~min}$ at room temperature. The DNA content was determined by a FACS Caliber flow cytometer (CyFlow SL, PartecGermany) and the cells were analyzed in different phases of G0, G1, S, and M. All experiments were performed in triplicates.

\section{Real-time quantitative polymerase chain reaction ( $R T$ - $q P(R)$}

After 72 hours exposure to IC50 concentrations of A. hamosus and paclitaxel, the expression of cell apoptosis markers was investigated by real time-PCR. The total RNA was extracted using RNX-Plus Solution kit (Sinaclon, Iran), converted to cDNA by First Strand cDNA Kit (Sinaclon, Iran). RT-qPCR was performed using the Rotor-Gene 6000 instrument (Corbett Life Science, USA). The comparative Ct method, $2^{-\Delta \Delta \mathrm{Ct}}$, was used for relative gene expression analysis. Results were reported as the relative expression normalized to the $\beta$-globin housekeeping gene, used as endogenous control. In each experiment, there were at least three different samples. Each stage was done in duplicates. The primers were designed using Primer 3 software and are listed in Table 2.

\section{Statistical analysis}

All data were expressed as means \pm standard errors of three independent experiments. After analysis of normality and homogeneity of variance using Kolmogorov-Smirnov test and Levene's test, Student's t-test, one-way ANOVA, and Tukey's post-hoc were used to determine the differences at $p<0.05$ significant level.

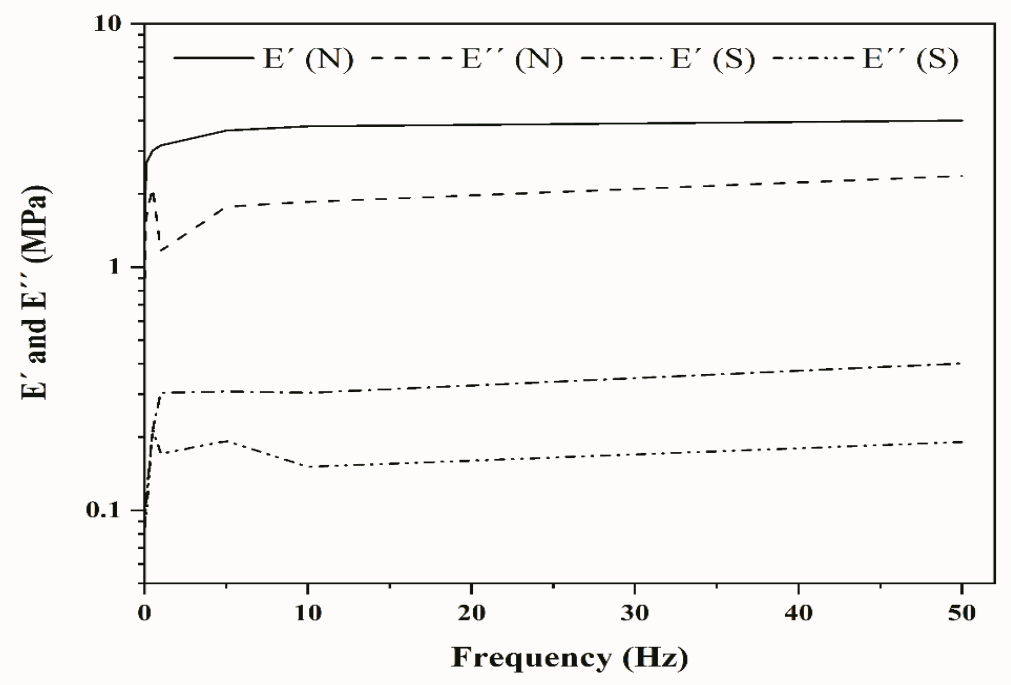

Figure 1. Dynamic- Mechanical Thermal Analysis (DMTA) behavior of BC Tissue and 3D Fibrin Gel. E' and E" denote elasticity and viscosity, respectively. Also, $\mathrm{N}$ and $\mathrm{S}$ stand for natural breast cancer and synthetic 3D fibrin gel 
Table 1. Different Concentrations of Involved Factors were Used in Construction of Fibrin Gel

\begin{tabular}{lcccc}
\hline Sample & $\begin{array}{c}\text { Fibrinogen } \\
(\mathrm{mg})\end{array}$ & $\begin{array}{c}\text { Thrombin } \\
(\mu \mathrm{L})\end{array}$ & $\begin{array}{c}\text { Cacl2 } \\
(\mu \mathrm{L})\end{array}$ & $\begin{array}{c}\text { FBS } \\
(\mu \mathrm{L})\end{array}$ \\
\hline 1 & 3 & 60 & 20 & 15 \\
2 & 3 & 60 & 60 & 15 \\
3 & 6 & 45 & 15 & 15 \\
4 & 6 & 45 & 45 & 15 \\
5 & 6 & 60 & 20 & 15 \\
6 & 6 & 60 & 60 & 15 \\
7 & 6 & 30 & 45 & 15 \\
\hline
\end{tabular}

\section{Results}

Dynamic mechanical behaviors of breast cancer tissue and $3 D$ fibrin scaffold

Since the natural BC tissue demonstrated better mechanical properties compared to fibrin scaffold, the viscoelastic behavior of tissue and fibrin scaffold was evaluated using DMTA at the temperature between $37^{\circ} \mathrm{C}$ and $40^{\circ} \mathrm{C}$. Figure 1 shows DMTA results related to sample 6 whose viscoelastic behaviors was closer to that of BC tissue. The $\mathrm{BC}$ tissue and fibrin gel sample had higher elasticity $\left(E^{\prime}\right)$ than viscosity $\left(E^{\prime \prime}\right)$. Also, in the frequency range studied which indicates different body movements, the behaviors of both samples were almost the same.

Total steroid value in terms of cholesterol in A. hamosus extract

The results of Lieberman-Bouchard test was done to determine the amount of steroids and cholesterol in the extract and $0.166 \%(\mathrm{w} / \mathrm{w})$ was recorded as total steroids weight percent in $A$. hamosus extract.

\section{$I C_{50}$ of $A$. hamosus extract and paclitaxel}

MCF-7 cells were treated with different concentrations of $A$. hamosus extract and paclitaxel for 72 hours to determine their $\mathrm{IC}_{50}$. The MTT results (Figure 2) showed that $A$. hamosus extract and paclitaxel decreased cell
Three-Dimensional (3D) Fibrin Gel Scaffold for Breast Cancer

Table 2. Primers Used for Real Time RT-PCR

\begin{tabular}{lll}
\hline Gene & & 5'à3’sequence \\
\hline$\beta$-globin & Forward & CACCTTTGCCACACTGAGTGAG \\
& Reverse & CCACTTTCTGATAGGCAGCCTG \\
Casp3 & Forward & GGAAGCGAATCAATGGACTCTGG \\
& Reverse & GCATCGACATCTGTACCAGACC \\
Casp8 & Forward & AGAAGAGGGTCATCCTGGGAGA \\
& Reverse & TCAGGACTTCCTTCAAGGCTGC \\
Casp9 & Forward & GTTTGAGGACCTTCGACCAGCT \\
& Reverse & CAACGTACCAGGAGCCACTCTT \\
Bcl2 & Forward & ATCGCCCTGTGGATGACTGAGT \\
& Reverse & GCCAGGAGAAATCAAACAGAGGC \\
\hline
\end{tabular}

viability of MCF-7 cells by increasing the concentration of treating agents. By curve fitting on the MTT data, the calculated $\mathrm{IC}_{50}$ of $A$. hamosus extract was $253.2 \pm 5.1 \mu \mathrm{g} / \mathrm{ml}$ while paclitaxel had $\mathrm{IC}_{50}$ at concentration of $0.097 \pm 0.008$ $\mu \mathrm{M} / \mathrm{ml}$ after 72 hours.

Considering nearest concentration to the $\mathrm{IC}_{50}$ amounts ( $250 \mu \mathrm{g} / \mathrm{ml}$ for A. hamosus and $0.1 \mu \mathrm{M} / \mathrm{ml}$ for Paclitaxel, respectively), the growth index (ratio of cell number at a certain time of culture period to the inoculation density) was determined from MTT assay at the end of 72-hours incubation period, which was $\sim 0.5$ for both drugs.

Size and morphology of MCF-7 spheroids

During 72-hours observation and at 24-hours interval, optical microscopic images were taken and average size of formed spheroids was calculated using ImageJ v1.50e. Figure 3 shows the morphologies of MCF-7 spheroids after 24, 48, and 72 hours. By time increasing, the average diameter of the MCF-7 spheroids increased from $33.59 \pm 0.22 \mu \mathrm{m}$ for 24-hours to $73.51 \pm 59 \mu \mathrm{m}$ for 48-hours and $88.04 \pm 0.21 \mu \mathrm{m}$ for 72 -hours incubation. Considering the average diameter of $20 \mu \mathrm{m}$ for MCF-7 [50] and assuming spherical shape for MCF-7 cells and spheroids, the average number of cells consisting of a spheroid are about 5, 50, and 85 cells for 24-hours, 48-hours, and 72-hours incubation, respectively.

\section{(A)}

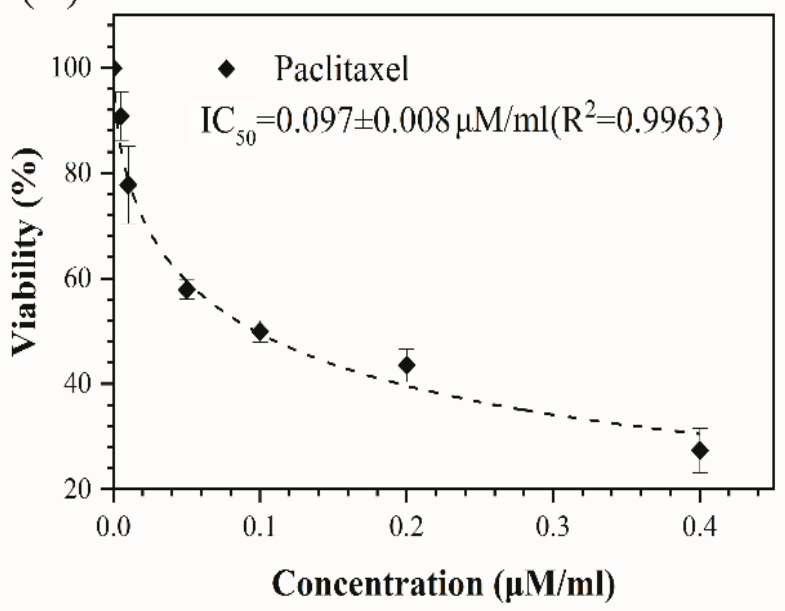

(B)

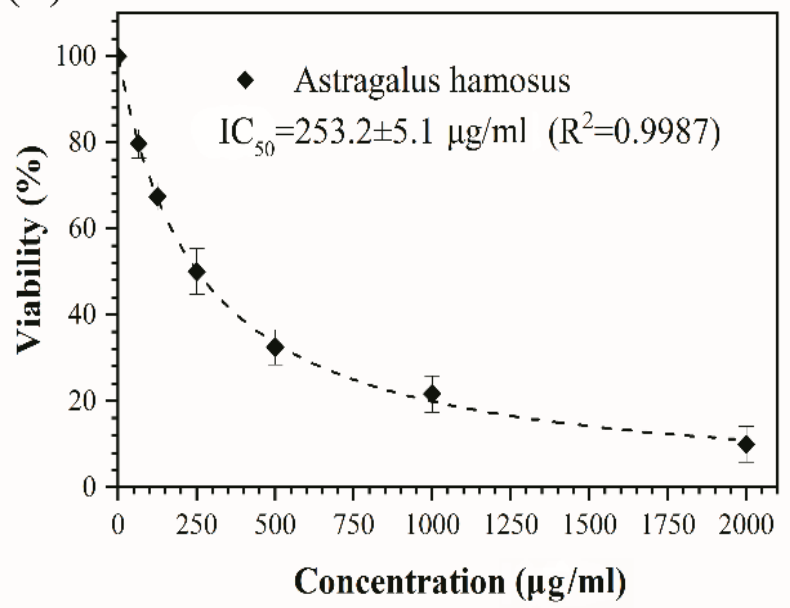

Figure 2. Viability and $\mathrm{IC}_{50}$ of MCF-7 Cells Treated with Various Concentrations of (A) MCF-7 Cells with Different Concentration of Paclitaxel and (B) MCF-7 with Different Concentration of A. hamosus in after 72 hours. 

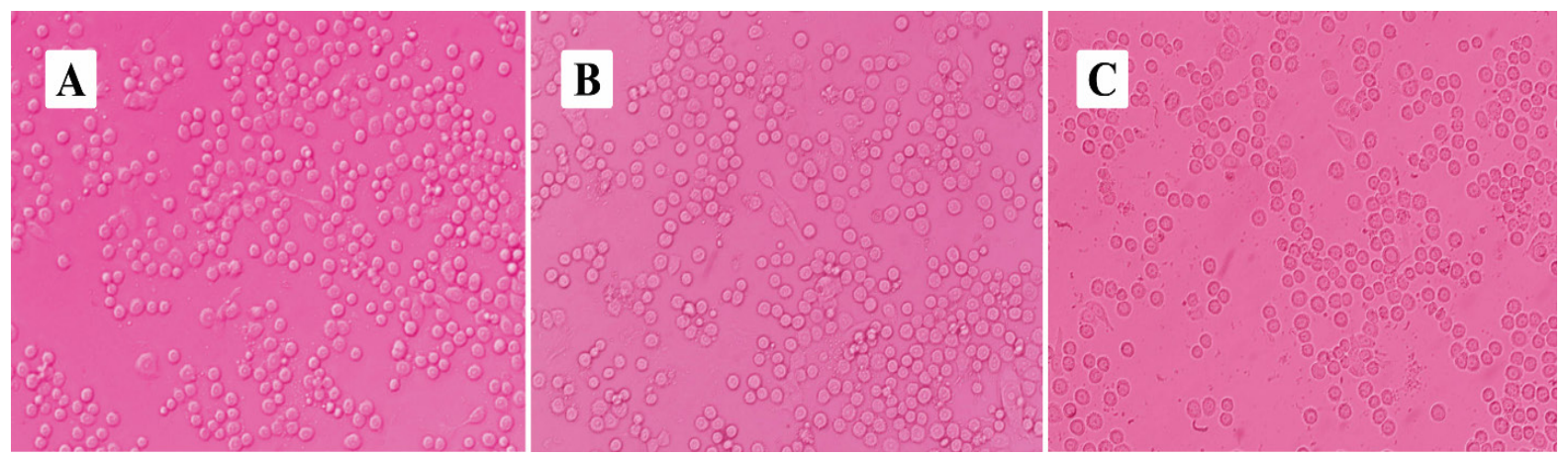

Figure 3. Optical Microscopic Images of MCF-7 Spheroid after (A) 24 hours (B) 48 hours and (C) 72 hours Incubation.
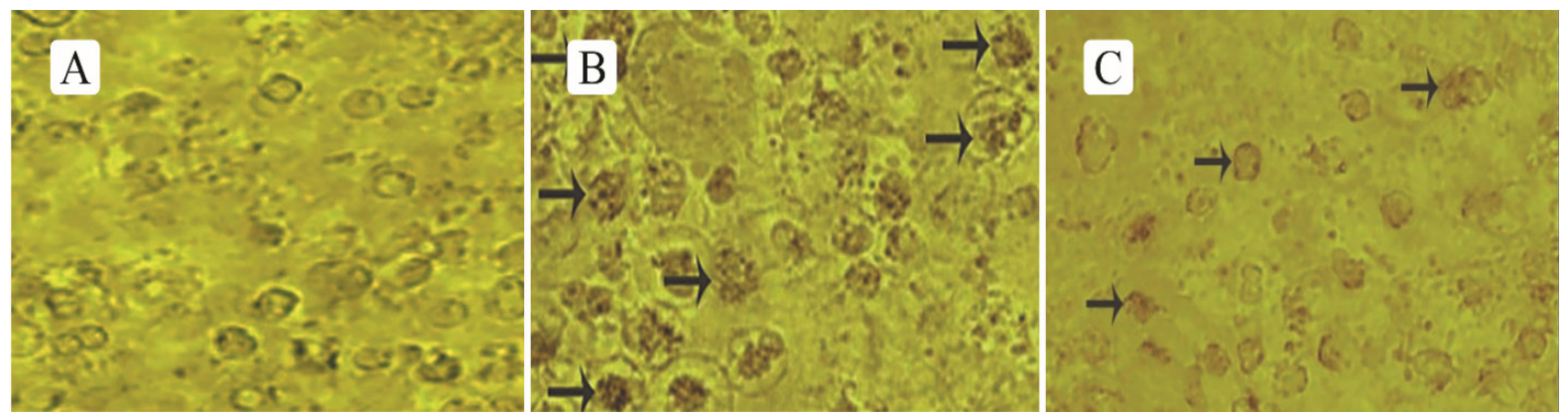

Figure 4. MCF-7 Cells Stained by the TUNEL Technique. (A) MCF-7 control (B) MCF-7 treated with paclitaxel (C) MCF-7 treated with A. hamosus showing abundant brown-stained cells. The brown color indicates apoptotic cells at $\mathrm{IC}_{50}$ of $A$. hamosus $(253 \mu \mathrm{g} / \mathrm{ml})$ and paclitaxel $(0.097 \mu \mathrm{M} / \mathrm{ml})$. Original magnifications $=40 \mathrm{x}$

\section{(I)}
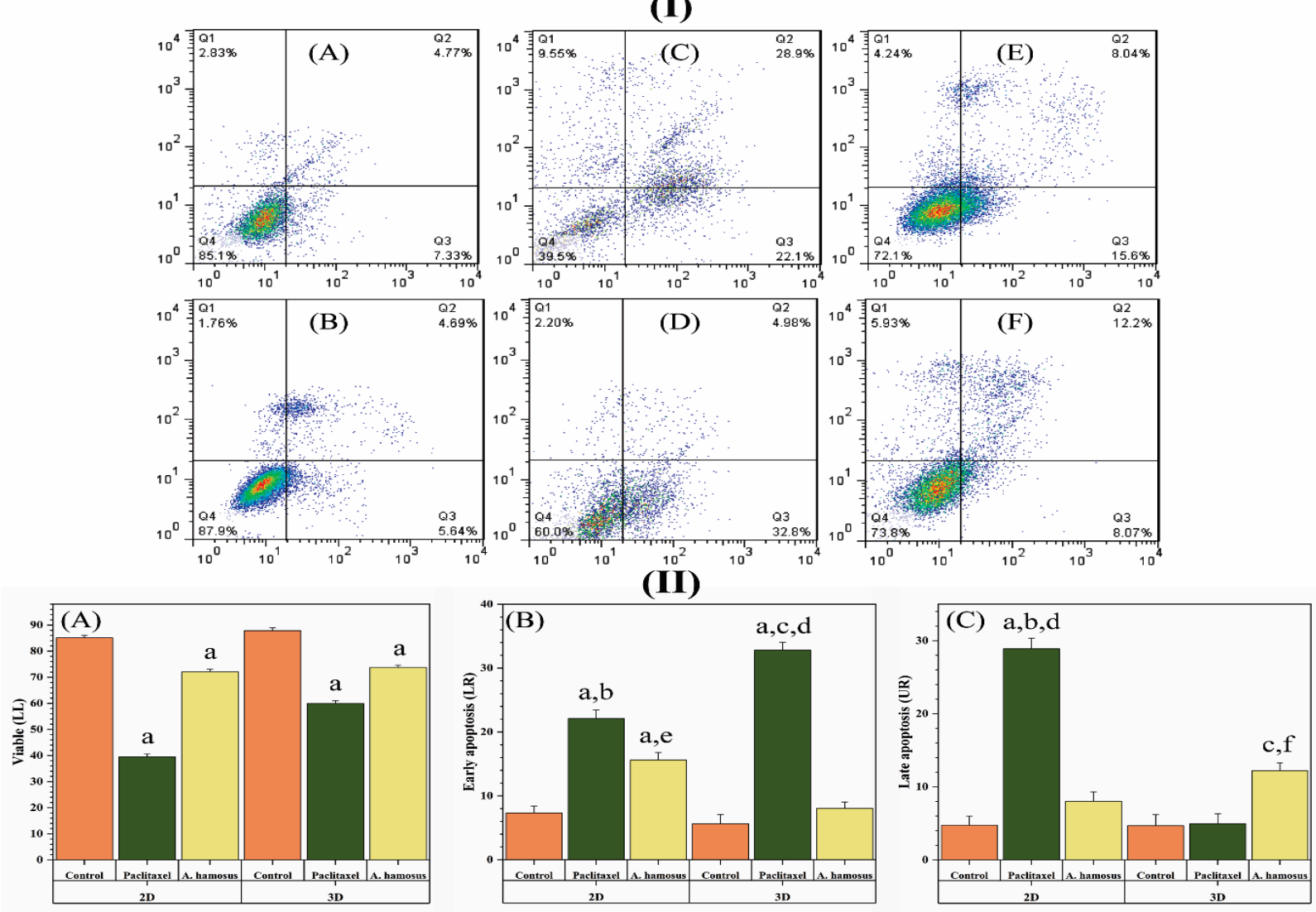

Figure 5. (I), Cell Apoptosis by Flow Cytometry Analysis of Treated MCF-7 Cells in 3D Fibrin Gel and 2D Culture (A, C, E: control, paclitaxel-, and A. hamosus-treated in 2D culture and B, D, F: control, paclitaxel-, and A. hamosustreated in fibrin gel); (II), (A) viable intact cells (B) early apoptotic cells (C) late apoptotic cells. Data show the means \pm standard deviation. Different groups were compared statistically by One-way ANOVA. (a: $p<0.001$ compared to control, b: $\mathrm{p}<0.001$ 2D paclitaxel-A. hamosus, c: $\mathrm{p}<0.00013 \mathrm{D}$ paclitaxel-A. hamosus, $\mathrm{d}$ : $\mathrm{p}<0.00012 \mathrm{D}-3 \mathrm{D}$ paclitaxel, e: $\mathrm{p}<0.0001$ 2D-3D A. hamosus, f: $\mathrm{p}<0.05$ 2D-3D A. hamosus). 


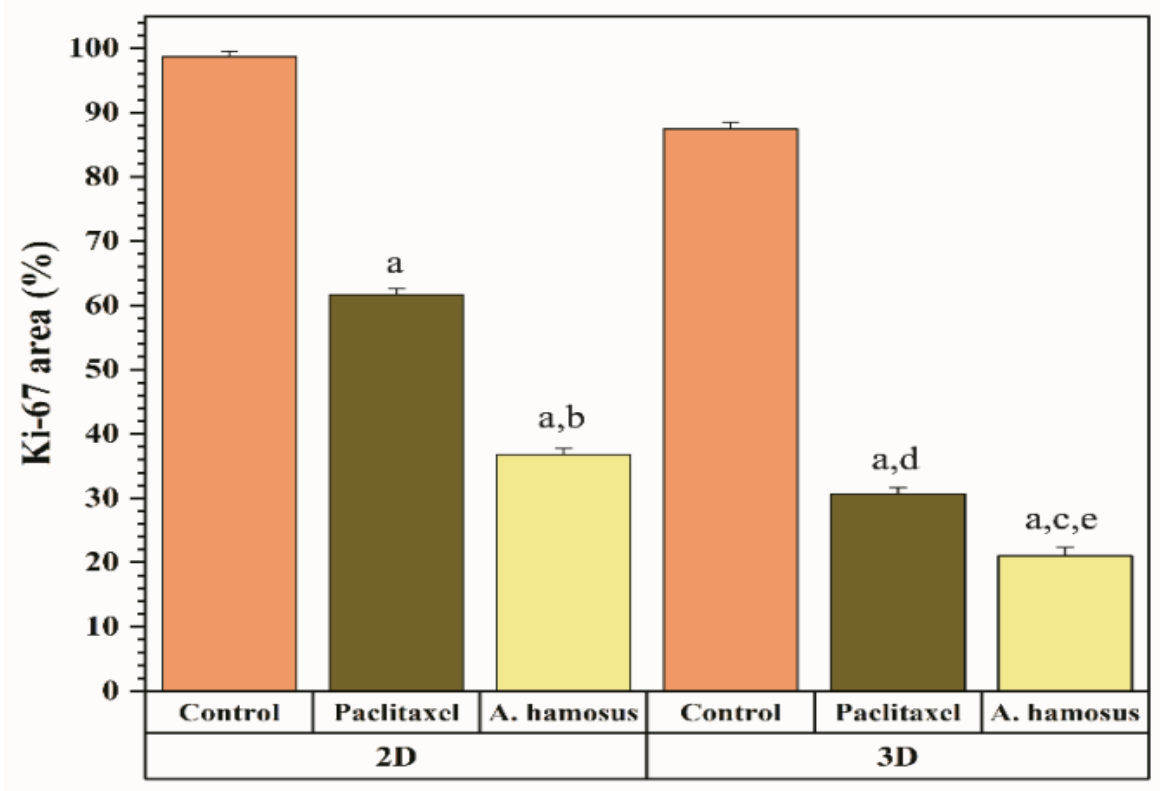

Figure 6. Percentage of Ki-67 Expression in MCF-7 Cells in 2D Culture and MCF-7 Spheroids Encapsulated in Fibrin Gel. Data show the means \pm standard deviation. Different groups were compared statistically by One-way ANOVA. (a: $\mathrm{p}<0.0001$ compared to control, b: $\mathrm{p}<0.00012 \mathrm{D}$ paclitaxel-A. hamosus, $\mathrm{c}: \mathrm{p}<0.0001$ 3D paclitaxel- $A$. hamosus, $\mathrm{d}$ : $\mathrm{p}<0.0001$ 2D-3D paclitaxel, e: $\mathrm{p}<0.0001$ 2D-3D A. hamosus).

\section{Apoptosis analyses}

The exposed cell to $\mathrm{IC}_{50}$ concentrations of $A$. hamosus extract and paclitaxel for 72 hours were harvested and examined by TUNEL assay. Figure 4 shows that nuclei of apoptotic cells absorb DAPI stain and become brown. The results indicated that both $A$. hamosus extract and paclitaxel induced morphological changes including cell shrinkage, nucleus fragmentation and typical apoptotic bodies.

The apoptosis index of MCF-7 cells in all groups was determined with Annexin $\mathrm{V}$ using flow cytometry analysis (Figure 5I). There was a significant difference between the $2 \mathrm{D}$ and $3 \mathrm{D}$ control cells and other groups in terms of early apoptosis index. The highest early apoptosis index was belonged to 3D paclitaxel group followed by 2D paclitaxel, 2D A. hamosus extract, 3D A. hamosus extract,

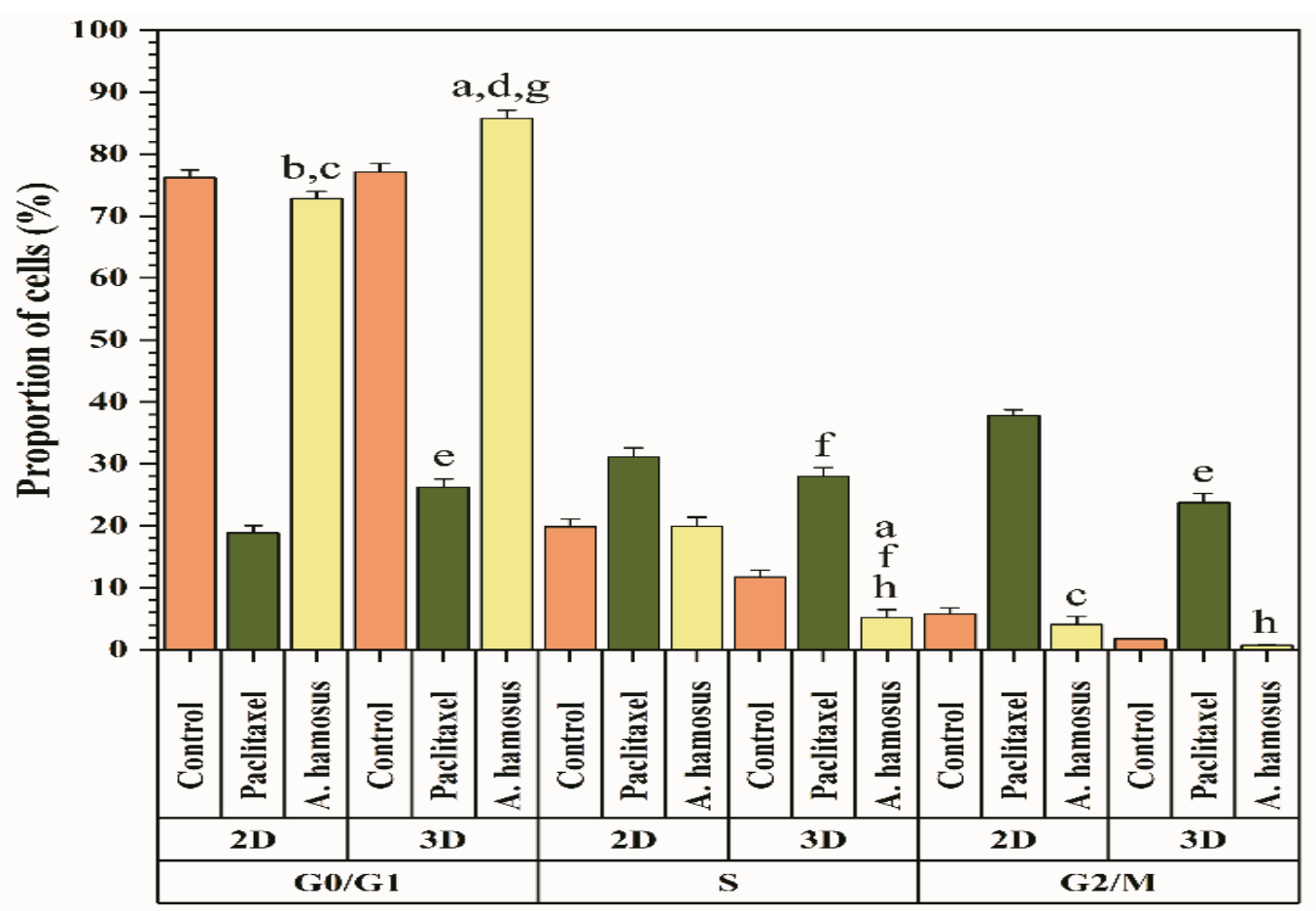

Figure 7. Cell Cycle Phases in MCF-7 Cell in 2D Culture and MCF-7 Spheroids Encapsulated in Fibrin Gel. Data show the means \pm standard deviation. Different groups were compared statistically by One-way ANOVA. (a: $\mathrm{p}<0.0001$ compared to control, b: $\mathrm{p}<0.05$ compared to control, $\mathrm{c}: \mathrm{p}<0.00012 \mathrm{D}$ paclitaxel-A. hamosus, $\mathrm{d}: \mathrm{p}<0.0001$ 3D paclitaxel- $A$. hamosus, e: $<<0.0001$ 2D-3D paclitaxel, f: $\mathrm{p}<0.05$ 2D-3D paclitaxel, g: $<<0.0001$ A. hamosus, h: $\mathrm{p}<0.01$ A. hamosus) 

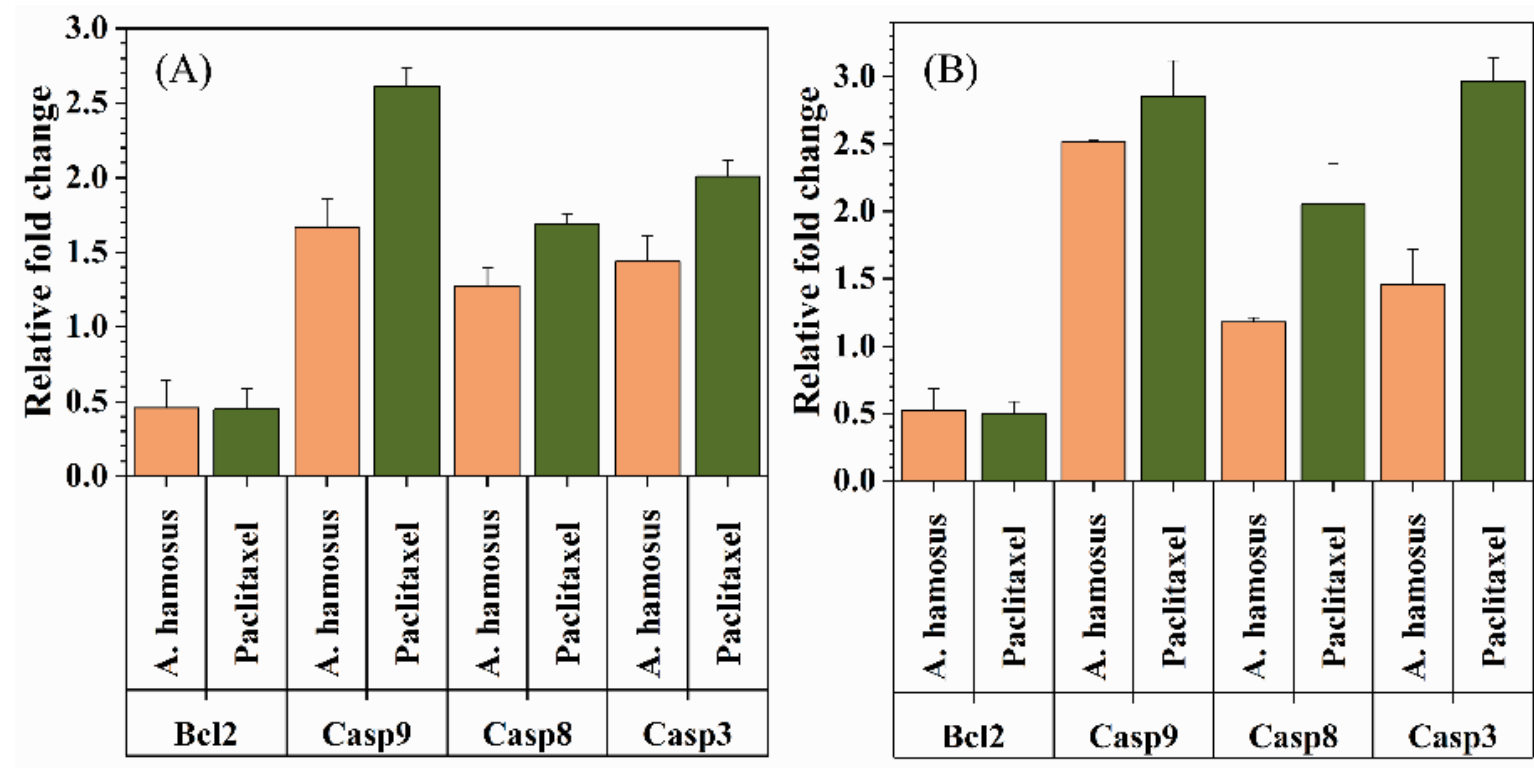

Figure 8. Real Time-PCR Analysis of the Pro-Apoptotic Genes (caspase-3, -8 and -9) and Anti-Apoptotic Gen Bcl-2 in (A) 2D culture of MCF-7 and (B) MCF-7 spheroid cells encapsulated in fibrin gel treated with A. hamosus and paclitaxel at the $\mathrm{IC}_{50}$ concentrations

and control groups, respectively (Figure 5II, B). The highest late apoptosis index was belonged to 2D paclitaxel followed by 3D A. hamosus and 2D A. hamosus groups. In contrast the lowest viable MCF-7 cells were belonged to $2 \mathrm{D}$ paclitaxel followed by $3 \mathrm{D}$ paclitaxel, 3D and 2D A. hamosus extract, and control groups (Figure 5II, C).

\section{Proliferation analyses}

Figure 6 shows Ki-67 area percent (presenting proliferative index) for MCF-7 cells and spheroids treated with paclitaxel and $A$. hamosus at $\mathrm{IC}_{50}$ concentrations under $2 \mathrm{D}$ and $3 \mathrm{D}$ culture conditions. The results showed significant decrease in Ki-67 expression after treatment with paclitaxel and $A$. hamosus in 3D fibrin gel compared to $2 \mathrm{D}$ culture. Moreover, the Ki67 expressions in the A. hamosus-treated MCF-7 cells under 2D and 3D conditions were lower than those of the paclitaxel-treated MCF-7 cells and spheroids.

\section{Cell cycle phases}

Extended investigation indicated obvious changes in percentages of cell cycle phases, whereG2/M and S phase showed significant reduction with marked elevation of G0/G1 phases in A. hamosus-treated MCF-7 spheroids encapsulated in fibrin gel compared to control group and paclitaxel-treated MCF-7 cells and spheroids (Figure 7); however, the percentage of $\mathrm{S}$ phase in 2D A. hamosus treatment was not significant compared to control group. Although three-dimensional treatment of MCF-7 spheroids with paclitaxel significantly increased the percentage of G0/G1 and decreased the percentages of S and G2/M compared to the 2D treatment, $A$. hamosus could keep its advanced position under $2 \mathrm{D}$ and $3 \mathrm{D}$ conditions.

\section{$q R T-P C R$}

Real-time PCR analysis showed that the relative expression level of caspase-3, -8 and -9 in 3D fibrin gel was significantly higher than the $2 \mathrm{D}$ treatment. The mean expression levels of Bcl-2 were similar for both 3D fibrin gel and 2D treatment (Figure 8). By 2D and 3D treatment of MCF-7 with paclitaxel, Bcl-2 expression decreased in comparison with $A$. hamosus, but not significantly.

\section{Discussion}

Promoting tumor cell apoptosis is one of the most important methods towards tumor treatment. Threedimensional culture system using fibrin gel is a good method for analysis of drug effects on tumor cells (Bayat et al., 2016). Biomaterials sometimes mimic tumor microenvironment allowing $3 \mathrm{D}$ space to investigate the behavior, response and progression of cancer cells (Hassan et al., 2021). A. hamosus is commonly used herb in traditional medicine. In the present study, a 3D fibrin gel was designed to investigate the apoptotic potency and anti-proliferative effect of $A$. hamosus extract on cell morphology, apoptosis, proliferation, and cell cycle of MCF-7 cells. To evaluate apoptotic effect of $A$. hamosus extract on BC cells in $3 \mathrm{D}$ and $2 \mathrm{D}$ culture, TUNEL and Annexin $\mathrm{V}$ assays as well as expression analysis of caspase-3, -8, -9, and Bcl-2 genes were investigated. Similar to BC tissue, DMTA results showed that the amount of elasticity $\left(\mathrm{E}^{\prime}\right)$ was higher than the viscosity $\left(E^{\prime \prime}\right)$ in the fibrin gel. The higher level of $E^{\prime}$ and $E^{\prime \prime}$ in the $\mathrm{BC}$ tissue than those of fibrin gel was due to stiffer structure of the $\mathrm{BC}$ tissue as a result of the presence of proteins and biomolecules as well as connections between the filaments and intermolecular bonds.

Evaluating cytotoxic activity by MTT assay revealed that the $\mathrm{IC}_{50}$ of paclitaxel was lower than that of $A$. hamosus extract which was expected due to intense effect of paclitaxel as a pure substance. However, growth indexes (ratio of cell number at a certain time of culture period to the inoculation density) for both substances were 
similar. Since $A$. hamosus extract is a mixture of effective and non-effective constituents, it is expected that isolation of effective components could apply more strong and controlled cytotoxic effect on MCF-7 cells at lower and safer concentrations.

Our findings indicated that the A. hamosus extract increased apoptosis in 3D fibrin gel compared to 2D culture. Flow cytometry analysis showed that the highest early and late apoptosis index as well as the lowest viable cells were belonged to 2D and 3D paclitaxel groups followed by $3 \mathrm{D}$ and $2 \mathrm{D} A$. hamosus groups confirming apoptosis induction by $A$. hamosus extract. In addition, we found that $\mathrm{S}$ and $\mathrm{G} 2 / \mathrm{M}$ phases of cell cycle were arrested in the A. hamosus-treated cells in 3D fibrin gel compared to control group. We found that caspase-3, -8 and -9 upregulated and the percentage of $\mathrm{Ki}-67$ decreased after treatment with $A$. hamosus extract in 3D fibrin gel compared to $2 \mathrm{D}$ culture.

The A. hamosus extract consists of different flavonoid compounds such as rutin, astragalin, hyperoside, and isoquercitrin (Ionkova, 1995) having antioxidant, anticancer, and anti- inflammatory properties (Ghodrati Azadi et al., 2008; Ghahremani-majd et al., 2012; Krejčová et al., 2014). It was proved that rutin component had an antiapoptotic activity against the MCF-7 cells, upregulated caspase gens significantly, and decreased volume of tumor, and level of carcinoembryonic antigen (CEA) (Saleh et al., 2019). Isoquercitrin is another important ingredient of A. hamosus and has strong activity against MCF-7 cells which could suppresses cell proliferation (Yang and Liu, 2009). Hyperoside is one of the flavonoid glycosides with anti-inflammatory, antidepressant, and anti-cancer effects. Investigating the effect of hyperoside on MCF-7 cells has been indicated that it acted as an anticancer drug through ROS-related apoptosis through activation of the Baxcaspase- 3 axis and the inhibition of the NF- $\kappa B$ signaling pathway (Qiu et al., 2020).

Although the expression of caspase-3, caspase-8, and especially caspase-9 increased significantly confirming apoptotic effect of $A$. hamosus under 2D and 3D conditions, its effect was not as great as the paclitaxel. Three-dimensional fibrin gel caused increase in expression of caspase-9 in A. hamosus-treated MCF-7 spheroids indicating activation of intrinsic apoptosis pathway (Elmore, 2007). To eliminate cells by executing apoptotic death early in development stage, caspase-9 is essential to inhibit proliferative diseases through the continuous removal of irreparable cells in the lifecycle ( $\mathrm{Li}$ et al., 2017). Meanwhile activation of intrinsic apoptosis pathway, paclitaxel caused little increase in expression of caspase- 8 in $3 \mathrm{D}$ condition compared to $2 \mathrm{D}$ treatment which proved enhanced extrinsic apoptosis pathway (Elmore, 2007). The expression of caspase-3 is the common route of apoptosis which increases by paclitaxel 3D treatment compared to A. hamosus. Caspase- 3 , as the most important of the executioner caspases which could be activated by other initiator caspases such as caspase- 8 and caspase-9 (Elmore, 2007), had higher expression level for paclitaxel compared to A. hamosus. Bayat (2016) (Bayat et al., 2016) provided a 3D model of glioma in fibrin gel with different concentrations of atorvastatin, and showed
Three-Dimensional (3D) Fibrin Gel Scaffold for Breast Cancer

that the most probable mechanisms are up-regulation of caspase- 8 and 3 . They suggested that this biomimetic model with fibrin may provide an appropriate 3D culture system to study the effect of anti-cancer drugs.

The anti-proliferative effect of $A$. hamosus can be attributed to its steroids content that was detected in the present study. Saponins are found in a wide range of plants. They have different carbon backbones that classify them as either triterpenes or steroids (Aung et al., 2017). Saponins alone or in combination with other conventional therapies have potent biological functions such as anti-tumor activity against several tumors by triggering apoptosis and causing cell cycle arrest (Man et al., 2010). Krasteva (2008) (Krasteva et al., 2008), evaluated the anti-proliferative effect of a saponins mixture and of a new flavonoid, isolated from $A$. hamosus against a panel of human tumor cell lines. The saponin mixture has been demonstrated to show inhibitory effects against a multidrug resistant cell line HL-60/Dox, and IC50 value was lower in the resistant sub-line in comparison with the chemo sensitive parent cell line HL-60. Dineva (2010) (Dineva et al., 2010) confirmed the antineoplastic activity of the saponin mixture, derived from $A$. hamosus, in two BC cell lines, including MDA-MB 231 estrogen receptor negative and $\mathrm{MCF}-7$ estrogen receptor positive. Moreover, the saponin mixtures decrease the expression level of the mitochondrial protein BclxL that outlines its influence on the cell death signal transduction.

In conclusion, our data clarified the base for the pharmacological use of $A$. hamosus extract in breast cancer. The anti-proliferative effect of this extract justified the further investigation of its antineoplastic potential. Furthermore, fibrin gel provided a suitable 3D scaffold to improve drug response in tissue engineering. This developed scaffold could be potentially used in future investigations of anti-cancer drugs.

\section{Abbreviations}

BC: Breast Cancer

A. hamosus: Astragalos Hamosus

\section{Author Contribution Statement}

Conceptualization: [Mozaffar Mahmoodi] and [Jafar Ai]; Methodology: [Somayeh Ebrahimi-Barough], [Mahmoud Azami], [Mozhgan Mehri], [Shagayegh Kamian], and [Mozaffar Mahmoodi]; Formal analysis and investigation: [Mozaffar Mahmoodi], [Mohammd Abdi], and [Somayeh Ebrahimi-Barough]; Writing-original draft preparation: [Mozaffar Mahmoodi]; Writing-review and editing: [Mozaffar Mahmoodi]; Funding acquisition: [Jafar Ai]; Resources: [Jafar Ai], [Mohammd Abdi]; Supervision: [Jafar Ai]. The authors read and approved the final manuscript.

\section{Acknowledgements}

This study was the result of a Ph.D. thesis financially supported by Tehran University of Medical Sciences (Grant/Award Numbers: IR.TUMS.VCR.REC.1397.980) and Kurdistan University of medical sciences (Grant/ 
Award Numbers: 'IR.MUK.REC.1398.226).

\section{Ethics approval and consent to participate}

This study was conducted under a protocol approved by the Ethical Committee of Tehran University of Medical Sciences (IR.TUMS.VCR.REC.1397.980).

\section{Consent for publication}

All the authors have approved the manuscript and agree with submission to your journal.

\section{Availability of data and material}

The datasets used and/or analyzed during the current study are available from the corresponding author upon reasonable request.

\section{Competing interests}

The authors declare that there is no conflict of interest.

\section{References}

Abbastabar H, Hamidifard P, Roustazadeh A, et al (2013). Relationships between breast cancer and common non-communicable disease risk factors: An ecological study. Asian Pac J Cancer Prev, 14, 5123-5.

Adu JK, Amengor CDK, Kabiri N, et al (2019). Validation of a simple and robust liebermann-burchard colorimetric method for the assay of cholesterol in selected milk products in Ghana. Int J Food Sci, 4, 269-72.

Afewerki S, Sheikhi A, Kannan S, et al (2019). Gelatinpolysaccharide composite scaffolds for 3D cell culture and tissue engineering: Towards natural therapeutics. Bioeng Transl Med, 4, 96-115.

Ahmed TAE, Dare EV, Hincke M (2008). Fibrin: a versatile scaffold for tissue engineering applications. Tissue Eng Part B Rev, 14, 199-215.

Ahn K (2017). The worldwide trend of using botanical drugs and strategies for developing global drugs. BMB Rep, 50, 111 .

Akinoglu EM, Ozbilgin K, Sonmez PK, et al (2017). Biocompatibility of vertically aligned multi-walled carbon nanotube scaffolds for human breast cancer cell line MDAMB-231. Prog Biomater, 6, 189-96.

Angeloni V, Contessi N, De Marco C, et al (2017). Polyurethane foam scaffold as in vitro model for breast cancer bone metastasis. Acta Biomater, 63, 306-16.

Aung TN, Qu Z, Kortschak RD, et al (2017). Understanding the effectiveness of natural compound mixtures in cancer through their molecular mode of action. Int J Mol Sci, 18, 656.

Bahcecioglu G, Basara G, Ellis BW, et al (2020). Breast cancer models: Engineering the tumor microenvironment. Acta Biomater, 106, 1-21.

Bayat N, Ebrahimi-Barough S, Norouzi-Javidan A, et al (2016). Apoptotic effect of atorvastatin in glioblastoma spheroids tumor cultured in fibrin gel. Biomed Pharmacother, 84, 1959-66.

Berezutskii MA, Yakubova LR, Durnova NA, et al (2020). Pharmacological properties of preparations based on Astragalus extract (Review). Pharm Chem J, 54, 372-6.

Carvalho MR, Lima D, Reis RL, et al (2017). Anti-cancer drug validation: the Contribution of Tissue Engineered Models. Stem Cell Rev, 13, 347-63.

Chie WC, Huang CS, Chen JH, et al (1999). Measurement of the quality of life during different clinical phases of breast cancer. J Formos Med Assoc, 98, 254-60.
Csupor-Löffler B, Hajdú Z, Zupkó I, et al (2009). Antiproliferative effect of flavonoids and sesquiterpenoids from Achillea millefolium s.l. on cultured human tumour cell lines. Phytother Res, 23, 672-6.

Darvishi N, Yousefinejad V, Akbari ME, et al (2020). Antioxidant and anti-inflammatory effects of oral propolis in patients with breast cancer treated with chemotherapy: a Randomized controlled trial. J Herb Med, 23, 100385.

Dineva I, Krasteva I, Berger M, et al (2010). In vitro antineoplastic activity of some cytoreductive drugs versus new compounds of plant origin. Int J Curr Chem, 1, 281-90.

Dunne LW, Huang Z, Meng W, et al (2014). Human decellularized adipose tissue scaffold as a model for breast cancer cell growth and drug treatments. Biomaterials, 35, 4940-9.

Duval K, Grover H, Han LH, et al (2017). Modeling physiological events in 2D vs. 3D cell culture. Physiol, 32, 266-77.

Elmore S (2007). Apoptosis: A review of programmed cell death. Toxicol Pathol, 35, 495-516.

Fobair P, Stewart SL, Chang S, et al (2006). Body image and sexual problems in young women with breast cancer. Psychooncol, 15, 579-94.

Foglietta F, Spagnoli GC, Muraro MG, et al (2018). Anticancer activity of paclitaxel-loaded keratin nanoparticles in twodimensional and perfused three-dimensional breast cancer models. Int J Nanomed, 13, 4847-67.

Ghahremani-majd H, Dashti F, Dastan D, et al (2012). Antioxidant and antimicrobial activities of Iranian mooseer (Allium hirtifolium Boiss) populations. Hortic Environ Biotechnol, 53, 116-22.

Ghodrati Azadi H, Ghaffari SM, Riazi GH, et al (2008). Antiproliferative activity of chloroformic extract of Persian Shallot, Allium hirtifolium, on tumor cell lines. Cytotechnology, 56, 179-85.

Ginsburg O, Bray F, Coleman MP, et al (2017). The global burden of women's cancers: a grand challenge in global health. Lancet, 389, 847-60.

Greenwell M, Rahman PKSM (2015). Medicinal plants: Their Use in Anticancer Treatment. Int J Pharm Sci, 6, 4103-12.

Guiro K, Patel SA, Greco SJ, et al (2015). Investigating Breast Cancer Cell Behavior Using Tissue Engineering Scaffolds. PLoS One, 10, e0118724.

Gurski LA, Jha AK, Zhang C, et al (2010). Corrigendum to "Hyaluronic acid-based hydrogels as 3D matrices for in vitro evaluation of chemotherapeutic drugs using poorly adherent prostate cancer cells. Biomaterials, 31, 4248.

Hamedi A, Zarshenas MM, Sohrabpour M (2016). Phytochemical assessments of Astragalus hamosus pods (Iklil-ul-Malik). Trends Pharmacol Sci, 2, 77-81.

Hasanzadeh E, Ebrahimi-Barough S, Mirzaei E, et al (2019). Preparation of fibrin gel scaffolds containing MWCNT/PU nanofibers for neural tissue engineering. J Biomed Mater $\operatorname{Res} A, \mathbf{1 0 7}, 802-14$.

Hassan G, Afify SM, Kitano S, et al (2021). Cancer stem cell microenvironment models with biomaterial scaffolds in vitro. Process, 9, 1-19.

Huang H, Ding Y, Sun XS, et al (2013). Peptide hydrogelation and cell encapsulation for $3 \mathrm{D}$ culture of MCF-7 breast cancer Cells. PLoS One, 8, e59482.

Ionkova I (1995). Astragalus species (milk vetch): in vitro culture and the production of saponins, astragaline, and other biologically active compounds. In 'Medicinal and Aromatic Plants VIII', Eds Springer, Berlin, Heidelberg, pp 97-138.

Kar S, Molla MS, Katti DR, et al (2019). Tissue-engineered nanoclay-based 3D in vitro breast cancer model for studying breast cancer metastasis to bone. J Tissue Eng Regen Med, 13, 119-30.

Krasteva I, Momekov G, Zdraveva P, et al (2008). Antiproliferative 
effects of a flavonoid and saponins from Astragalus hamosus against human tumor cell lines. Pharmacogn Mag, 4, $269-72$.

Krejčová P, Kučerová P, Stafford GI, et al (2014). Antiinflammatory and neurological activity of pyrithione and related sulfur-containing pyridine $\mathrm{N}$-oxides from Persian shallot (Allium stipitatum). J Ethnopharmacol, 154, 176-82.

Lequeux C, Oni G, Wong C, et al (2012). Subcutaneous fat tissue engineering using autologous adipose-derived stem cells seeded onto a collagen scaffold. Plast Reconstr Surg, 130, 1208-17.

Li P, Zhou L, Zhao T, et al (2017). Caspase-9: Structure, mechanisms and clinical application. Oncotarget, 8, 23996-4008.

Li W, Hu X, Yang S, et al (2019a). A novel tissue-engineered 3D tumor model for anti-cancer drug discovery. Biofabrication, 11, 15004.

Li W, Song K, Wang S, et al (2019b). Anti-tumor potential of astragalus polysaccharides on breast cancer cell line mediated by macrophage activation. Mater Sci Eng C, 98, 685-95.

Lysiuk R, Darmohray R (2016). Pharmacology and ethnomedicine of the Genus Astragalus. Int $J$ Pharmacol Phytochem Ethnomed, 3, 46-53.

Mahmoodi M, Ferdowsi S, Ebrahimi-Barough S, et al (2020). Tissue engineering applications in breast cancer. J Med Eng Technol, 44, 162-8.

Malafaya PB, Silva GA, Reis RL (2007). Natural-origin polymers as carriers and scaffolds for biomolecules and cell delivery in tissue engineering applications. Adv Drug Deliv Rev, 59, 207-33.

Man S, Gao W, Zhang Y, et al (2010). Chemical study and medical application of saponins as anti-cancer agents. Fitoterapia, 81, 703-14.

Menbari MN, Rahimi K, Ahmadi A, et al (2020). miR-483-3p suppresses the proliferation and progression of human triple negative breast cancer cells by targeting the HDAC8>oncogene. J Cell Physiol, 235, 2631-42.

Montazeri A, Vahdaninia M, Harirchi I, et al (2008). Breast cancer in Iran: need for greater women awareness of warning signs and effective screening methods. Asia Pac Fam Med, 7, 6.

Moon HS, Kwon K, Hyun KA, et al (2013). Continual collection and re-separation of circulating tumor cells from blood using multi-stage multi-orifice flow fractionation. Biomicrofluidics, 7, 14105.

Noori A, Ashrafi SJ, Vaez-Ghaemi R, et al (2017). A review of fibrin and fibrin composites for bone tissue engineering. Int J Nanomed, 12, 4937-61.

Pollard JW (2009). Trophic macrophages in development and disease. Nat Rev Immunol, 9, 259-70.

Qiu J, Zhang T, Zhu X, et al (2020). Hyperoside induces breast cancer cells apoptosis via ROS-mediated NF- $\mathrm{\kappa B}$ signaling pathway. Int J Mol Sci, 21, 131.

Saleem S, Shaharyar MA, Khusroo MJ, et al (2013). Anticancer potential of rhamnocitrin 4'- $\beta$-d-galactopyranoside against $\mathrm{N}$-diethylnitrosamine-induced hepatocellular carcinoma in rats. Mol Cell Biochem, 384, 147-53.

Saleh A, ElFayoumi HM, Youns M, et al (2019). Rutin and orlistat produce antitumor effects via antioxidant and apoptotic actions. Naunyn-Schmiedeb Arch Pharmacol, 392, 165-75.

Shkondrov A, Krasteva I, Ionkova I, et al (2019). Production of saponins from in vitro cultures of Astragalus glycyphyllos and their antineoplastic activity. Biotechnol Biotechnol Equip, 33, 1413-8.

Shojaii A, Motaghinejad M, Norouzi S, et al (2015). Evaluation of anti-inflammatory and analgesic activity of the extract and
Three-Dimensional (3D) Fibrin Gel Scaffold for Breast Cancer

fractions of Astragalus hamosus in animal models. Iran $J$ Pharm Sci, 14, 263-9.

Sims-Mourtada J, Niamat RA, Samuel S, et al (2014). Enrichment of breast cancer stem-like cells by growth on electrospun polycaprolactone-chitosan nanofiber scaffolds. Int J Nanomed, 9, 995-1003.

Vali F, Changizi V, Safa M (2015). Synergistic apoptotic effect of crocin and paclitaxel or crocin and radiation on MCF-7 cells, a type of breast cancer cell line. Int J Breast Cancer, 2015.

Vantangoli MM, Madnick SJ, Huse SM, et al (2015). MCF-7 human breast cancer cells form differentiated microtissues in scaffold-free hydrogels. PLoS One, 10, e0135426.

Wang X, Sun L, Maffini MV, et al (2010). A complex 3D human tissue cultu6e system based on mammary stromal cells and silk scaffolds for modeling breast morphogenesis and function. Biomaterials, 31, 3920-9.

Yakavets I, Francois A, Benoit A, et al (2020). Advanced co-culture 3D breast cancer model for investigation of fibrosis induced by external stimuli: optimization study. Sci Rep, 10, 1-11.

Yang J, Liu RH (2009). Synergistic effect of apple extracts and quercetin 3- $\beta$-D-glucoside combination on antiproliferative activity in MCF-7 human breast cancer cells in vitro. $J$ Agric Food Chem, 57, 8581-6.

Zhang Y, Leonard M, Shu Y, et al (2017). Overcoming tamoxifen resistance of human breast cancer by targeted gene silencing using multifunctional pRNA nanoparticles. ACS Nano, 11, 335-46.

Zuo KQ, Zhang XP, Zou J, et al (2010). Establishment of a paclitaxel resistant human breast cancer cell strain (MCF-7/ Taxol) and intracellular paclitaxel binding protein analysis. Int J Med Res, 38, 1428-35.

\section{(ब) $(\mathbb{8}$}

This work is licensed under a Creative Commons AttributionNon Commercial 4.0 International License. 